\title{
The Association between Highly Sensitive C-Reactive Protein and Interleukin-18 with Nephropathy in a Sample of Type 1 Diabetic Egyptian Patients
}

\author{
HANAN A. TAHA, M.D.*; HEBA H. MAHMOUD, M.D.*; AYMAN S. SOLIMAN, M.D.**; \\ MOHAMMED M. TAHA, M.D.* and RABAB A. MOHAMMED, M.D.*** \\ The Departments of Internal Medicine*, Physiology** and Clinical \& Chemical Pathology***, Faculty of Medicine, \\ Beni-Suef University, Egypt
}

\begin{abstract}
Background: Diabetic Nephropathy (DN) is a major complication of diabetes and the leading cause of end-stage renal disease that accounts for a large proportion of the excess mortality associated with Type-1 Diabetes (T1D). Inflammation and endothelial dysfunction have been hypothesized to play a role in the pathogenesis of DN. Highly sensitivity C-Reactive Protein (hs-CRP) and Interleukin-18 (IL-18) are associated with systemic inflammation and have been shown to be increased in individuals with Type 1 Diabetic nephropathy.
\end{abstract}

Aim of Study: In our study, we aim to determine the association between hs-CRP and IL-18 with nephropathy in a sample of type 1 diabetic Egyptian patients.

Patients and Methods: This study was conducted on 30 type-1 diabetic patients (Group I), who subdivided into three subgroups according to their urine Albumin Excretion Rate (AER); Group IA: 10 patients with AER $<20$ g/in, Group IB: 10 patients with AER ranges from 20-200 g/min. Group IC: 10 patients with AER is $>200 \mathrm{~g} / \mathrm{min}$ and 10 healthy subjects as a control (Group II). Patients and control were subjected to full history taking, full clinical examination, Fasting Plasma Glucose (FPG), Glycated Hemoglobin $\left(\mathrm{HbA}_{1 \mathrm{c}} \%\right)$, serum creatinine, Urinary Albumin Excretion (UAE), Highly-sensitive C-Reactive Protein (hs-CRP) by turbidimetry technique and Interleukin-18 (IL-18) by Enzymelinked Immunosorbent Assay (ELIZA) technique. This work was done during the year 2017.

Results: There were statistically significant difference between control group and diabetic group regarding hs-CRP $(4.25 \pm 6.62,25.13 \pm 23.56)$, and IL-18 $(2.85 \pm 0.74,12.68 \pm$ $29.12)$ with $(p=0.009, p=0.037)$ respectively. In diabetic group, we found a positive significant correlation $(p<0.001, p=0.012)$ between UAE and both; levels of hs-CRP $(r=0.765)$, and IL$18(r=0.453)$, respectively.

Conclusion: Hs-CRP and IL-18 are sensitive markers for diabetic nephropathy in type-1 diabetic patients.

Correspondence to: Dr. Hanan A. Taha, The Department of Internal Medicine, Faculty of Medicine, Beni-Suef University, Egypt
Key Words: Type-1 Diabetes (T1D) - Diabetic Nephropathy $(D N)-h s-C R P-I L-18$.

\section{Introduction}

THE term Diabetes Mellitus (DM) describes a metabolic disorder with heterogenous etiology which is characterized by chronic hyperglycemia and disturbances of carbohydrate, fat and protein metabolism resulting from defects in insulin secretion, insulin action, or both. The long-term relatively specific effects of diabetes include development of retinopathy, nephropathy and neuropathy. People with diabetes are also at increased risk of cardiac, peripheral arterial and cerebrovascular disease [1]

The American Diabetes Association Committee recommends the term type $1 \mathrm{~A}$ diabetes for immune mediated diabetes with its destruction of the islet $\beta$ cells of the pancreas, non-immune mediated diabetes with severe insulin deficiency is termed type 1B. At present, the development of Type 1 Diabetes (T1D) is a life sentence to a difficult therapeutic regimen that is only partially effective in preventing acute and chronic complications [2]

Type 1A diabetes develops from a chronic autoimmune process leading to absolute insulin deficiency and proneness to ketosis. Prospective studies have clearly shown that intensive insulin therapy results in improved quality of life and reduced development of diabetes-associated microvascular and macrovascular complications [3]

Diabetic kidney disease, or Diabetic Nephropathy (DN) is a major complication of diabetes and the leading cause of end-stage renal disease that requires dialysis treatment or kidney transplanta- 
tion. In addition to the decrease in the quality of life, DN accounts for a large proportion of the excess mortality associated with T1D [4].

Progressive nephropathy represents a substantial source of morbidity and mortality in T1D. Increasing albuminuria is a strong predictor of progressive renal dysfunction and heightened cardiovascular risk. Early albuminuria probably reflects vascular endothelial dysfunction, which may be mediated in part by chronic inflammation [5].

The concept of the underlying pathophysiologic processes leading to DN has evolved tremendously. In the classical view, renal injury in these patients is explained by metabolic and hemodynamic alterations, which increase systemic and intraglomerular pressure, and by the modification of molecules under hyperglycemic conditions. This view has evolved to a much more complex scenario, where the pathogenesis of DN appears as multifactorial, with both genetic and environmental factors triggering a complex series of pathophysiological events. Intensive research in recent years on the etiology of DN at the cellular and molecular level has given rise to inflammation as a key pathophysiological mechanism [6] .

Understanding the key features of inflammatory mechanisms involved in the development and progression of diabetic kidney injury will enable the identification of new potential targets and facilitate the design of innovative anti-inflammatory therapeutic strategies [7].

Several acute-phase inflammatory markers have been reported to be increased in T1D. Highly sensitivity C-Reactive Protein (hs-CRP) is an acutephase protein that is associated with systemic inflammation and has been shown to be increased in individuals with coronary artery disease. In many studies, hs-CRP was elevated in newly diagnosed youth and adults with T1D [8].

Interleukin-18 (IL-18) is one of type 1 cytokines primarily produced by macrophages and closely related to the IL-1 family of cytokines. It was shown that IL-18 played a key role in the generation of type 1 cytokines responses by up-regulating the interferon (IFN)- $\gamma$ production from T cells and natural killer cells through a concerted action with IL-12. An up-regulated production of IL-18 could therefore be an important pathogenic event in the dysregulated production of IFN- $\gamma$ and other type 1 cytokines thought to predispose immunoinflammatory diseases such as Type 1 Diabetes Mellitus (T1 DM). It was recently reported that IL-18 serum levels are increased in the subclinical stage of
T1DM in first-degree relatives of T1DM patients indicating that IL-18 could play a part in the pathogenesis of T1 DM [9].

It was estimated that in 2017 there are 451 million (age 18-99 years) people with diabetes worldwide. These figures were expected to increase to 693 million by 2045 . It was estimated that almost half of all people (49.7\%) living with diabetes are undiagnosed. Moreover, there was an estimated 374 million people with Impaired Glucose Tolerance (IGT) and it was projected that almost 21.3 million live births to women were affected by some form of hyperglycaemia in pregnancy. In 2017, approximately 5 million deaths worldwide were attributable to diabetes in the 20-99 years age range. The global healthcare expenditure on people with diabetes was estimated to be USD 850 billion in 2017 [10]

\section{Subjects and Methods}

The present study was conducted on 40 individuals; 30 of them are type 1 diabetic patients and 10 are normal individuals, they were selected from patients attending the outpatient clinics of Internal Medicine Department in Beni-Suef University Hospital. The current work was done during the year 2017. A written consent was taken from each person included in this study whether in patients' group or normal control group.

\section{The individuals were divided into 2 main groups:}

I- Diabetic group: 30 patients with type-1 diabetes mellitus, their ages ranged from 16-39 years old with a mean of $26.966 \pm 7.35$ years. They were subdivided into 3 subgroups according to their urine Albumin Excretion Rate (AER);

- Subgroup A: 10 (4 females and 6 males) type-1 diabetic patients with AER less than $20 \mathrm{~g} / \mathrm{m}$ in (normoalbuminurea), their ages ranged from 1631 years old with mean of $(21.5 \pm 5.83)$ years and the main duration of DM ranged from 3-14 years with mean of $(6.3 \pm 3.301)$ years.

- Subgroup B: 10 (7 females and 3 males) type-1 diabetic patients with AER ranges from 20-200 a min (microalbuminurea), their ages ranged from 17-36 years old with mean of $(25.2 \pm 6.528)$ years and the main duration of DM ranged from 7-11 years with mean of $(8.9 \pm 1.197)$ years.

- Subgroup C: 10 (5 females and 5 males) type-1 diabetic patients with AER more than $200 \mathrm{~g} / \mathrm{m}$ in (macroalbuminurea), their ages ranged from 3039 years old with mean of $(34.2 \pm 2.87)$ years and the main duration of DM ranged from 10-24 years with mean of $(15.6 \pm 4.788)$ years. 
II- Control group: 10 normal healthy individuals (7 females and 3 males) with ages ranged from 1328 years old with mean of $(19.4 \pm 5.165)$ years with age matching as a control.

\section{Exclusion criteria:}

Type-1 diabetic patients on dialysis.

\section{Methods:}

Patients and controls were subjected to the following:

I- History taking: Including drug history with insulin dose and other drugs if found in particular; antihypertensive drugs intake, course of the disease and complications if found, history of administration to hospitals and family history of diabetes.

II- Full clinical examination: Including: General examination, chest, heart, abdomen and neurological examination.

III- Laboratory investigations: Sample collections: An overnight fasting (8-10 hours) venous blood sample was collected from each subject using a sterile plastic syringe. One portion of the collected blood was taken on Ethylene-Diaminetetra-Acetic Acid (EDTA) containing tube for measurement of $\mathrm{HbA}_{1 \mathrm{c}} \%$. The remainder of the blood was allowed to clot for 10-20 minutes at room temperature then centrifuged for 20 minutes at the speed of 2000-3000r.p.m to separate the serum. One portion of the serum was used immediately for the measurement of FPG and creatinine. The other portion was stored in epindorph tubes in a deep freeze at $-20^{\circ} \mathrm{C}$ till tested for hs-CRP and IL-18. Serum samples are stable for 7 days at $2-8^{\circ} \mathrm{C}$ or 3 months at $-20^{\circ} \mathrm{C}$. Urine samples were taken from patients in tubes then centrifuged for 20 minutes at the speed of 2000-3000r.p.m and examined for microalbuminurea within a week.

\section{Biochemical assays:}

Fasting Plasma Glucose (FPG), Glycated hemoglobin $\left(\mathrm{HbA}_{1 \mathrm{c}} \%\right)$, serum creatinine, Urinary Albumin Excretion (UAE) and highly-sensitive CReactive Protein (hs-CRP) by turbidimetry technique. The CRP-ultra sensitive is a quantitative turbidimetric test for the measurement of low levels of CRP in human serum or plasma.

Interleukin-18 (IL-18) level was measured by Enzyme-Linked Immunosorbent Assay (ELIZA) technique. The Human IL-18 ELISA Kit is based on sandwich ELISA and can measure human IL18. Serum were stored at $20^{\circ} \mathrm{C}$ before processing and equilibrated with room temperature before testing. All previously mentioned biochemical assays were done for all samples of the study groups. For all biochemical assays, the manufacturer instructions were followed.

\section{Statistical analysis:}

Data were collected, verified, revised then edited on personal computer. Data were coded and entered using the statistical package SPSS (Statistical Package for the Social Science; SPSS Inc., Chicago, IL, USA) Version 22.

\section{Results}

Comparison between diabetic patients and control group:

Data of the present study showed a highly statistically significant differences regarding; the duration of diabetes, Systolic Blood Pressure (SPB) and Diastolic Blood Pressure (DPB). On the other hand, it shows non significant differences regarding; age and sex (Table 1).

Table (1): Comparison between diabetic groups and control group regarding the different variants.

\begin{tabular}{llllll}
\hline Variable & $\begin{array}{c}\text { Control group } \\
\text { Mean } \pm \text { SD }\end{array}$ & $\begin{array}{c}\text { Diabetic group } \\
\text { Mean } \pm \text { SD }\end{array}$ & F & $p$ & Sig. \\
\hline Age (year) & $19.4 \pm 5.16$ & $26.96 \pm 7.35$ & 1.98 & 0.07 & N.S \\
$\begin{array}{l}\text { Sex: } \\
\quad \text { Male }\end{array}$ & 3 & 14 & & $>0.05$ & N.S \\
$\quad$ Female & 7 & 16 & & & \\
SBP (mmHg) & $109.5 \pm 7.61$ & $130.5 \pm 14.08$ & 27.94 & $<0.001$ & H.S \\
DBP (mmHg) & $71.5 \pm 7.09$ & $76.5 \pm 8.75$ & 13.53 & $<0.001$ & H.S \\
HbA $1 \mathrm{c} \%$ & $5.13 \pm 0.66$ & $7.56 \pm 1.96$ & 6.24 & $<0.001$ & H.S \\
UAE ( g /min) & $6.54 \pm 8.37$ & $132.05 \pm 173.45$ & 24.4 & 0.007 & Sig \\
S.Creatinine (mg/dl) & $0.79 \pm 0.19$ & $1.5 \pm 1.29$ & 9.08 & 0.096 & N.S \\
Hs-CRP (mg/l) & $4.25 \pm 6.62$ & $25.13 \pm 23.56$ & 20.23 & 0.009 & Sig \\
IL-18 (ng/l) & $2.85 \pm 0.74$ & $12.68 \pm 29.12$ & 3.13 & 0.037 & Sig \\
\hline$p>0.05:$ Non-Significant (N.S). $\quad p<0.05:$ Significant (Sig). $\quad p<0.001:$ Highly Significant (H.S).
\end{tabular}


Also, there was statistically significant differences between diabetic group and control group regarding; UAE, hs-CRP and IL-18, and shows a highly significant difference regarding; $\mathrm{HbA}_{1 \mathrm{c}}$ and FPG. While it shows statistically non significant differences regarding; serum creatinine (Table 1).

Comparison between diabetic groups regarding the demographic, clinical and laboratory variants: Our study results show statistically highly signif- icant differences between diabetic subgroups regarding; age, duration of diabetes, SPB and DPB, and shows statistically non significant differences regarding; sex (Table 2).

Also, our results showed highly statistically significant differences between diabetic subgroups regarding; UAE, serum creatinine and hs-CRP, while it shows non significant differences regarding; $\mathrm{HbA}_{l_{c}}$, FPG and IL-18 (Table 2).

Table (2): Comparison between diabetic groups regarding the different variants.

\begin{tabular}{lccc}
\hline Variable & $\begin{array}{c}\text { Diabetic subgroup (A) } \\
\text { (Normoalbuminuria) } \\
\text { Mean } \pm \text { SD }\end{array}$ & $\begin{array}{c}\text { Diabetic subgroup (B) } \\
\text { (Microalbuminuria) } \\
\text { Mean } \pm \text { SD }\end{array}$ & $\begin{array}{c}\text { Diabetic subgroup (C) } \\
\text { (Macroalbuminuria) } \\
\text { Mean } \pm \text { SD }\end{array}$ \\
\hline Age (year) & $21.5 \pm 5.38$ & $25.2 \pm 6.52$ & $34.2 \pm 2.78 \# @$ \\
Duration of DM (year) & $6.3 \pm 3.3$ & $8.9 \pm 1.19 \#$ & $15.6 \pm 4.78 \# @$ \\
SBP (mmHg) & $121 \pm 7.74$ & $130.5 \pm 10.65$ & $141.56 \# @$ \\
DBP (mmHg) & $77.5 \pm 5.4$ & $80 \pm 8.16$ & $89 \pm 3.16 \# @$ \\
HbA $1_{\mathrm{c}} \%$ & $7.53 \pm 2.612$ & $7.96 \pm 2.15$ & $7.19 \pm 0.78$ \\
FPG (mg/dl) & $406.9 \pm 145.05$ & $340.7 \pm 112.43$ & $279.3 \pm 138.31$ \\
UAE ( g $/$ min) & $5.45 \pm 4.57$ & $49.2 \pm 30.13 \#$ & $341.5 \pm 147.77 \# @$ \\
S. Creatinine (mg/dl) & $0.78 \pm 0.23$ & $0.78 \pm 0.25$ & $2.94 \pm 1.36 \# @$ \\
Hs-CRP (mg/l) & $10.84 \pm 12.86$ & $14.09 \pm 16.29$ & $50.48 \pm 16.8 \# @$ \\
IL-18 (ng/l) & $4.5 \pm 4.39$ & $3.5 \pm 1.29$ & $30.05 \pm 47$ \\
\hline
\end{tabular}

\#: Significant as compare to diabetic subgroup (A).

@: Significant as compare to diabetic subgroup (B).

By comparing diabetic groups, we found that; by increasing the duration of diabetes, (UAE, SPB and DPB) are accompanied by higher levels of hs$\mathrm{CRP}$ and serum creatinine with no significant changes in IL-18 levels. This suggests the role of hs-CRP as an indicator of nephropathy and microvascular complications in type-1 DM in addition with the role of hypertension.

Current study data revealed a statistically significant difference between subgroup A and subgroup B regarding the duration of DM. Also, it shows a highly statistically significant difference regarding UAE, and shows a non significant differences regarding; age, SPB, DPB, $\mathrm{HbA}{ }_{1_{c}}$, FPG, serum creatinine, hs-CRP and IL-18 (Table 2). By comparing between diabetic subgroup $\mathrm{C}$ and subgroup B, results of the present study demonstrated highly statistically significant differences regarding (age, duration of DM, SPB, DPB, UAE, serum creatinine and hs-CRP) and show non significant differences regarding (FPG, $\mathrm{HbA}_{1 \mathrm{c}}$ and IL-18) (Table 2).

We found that diabetic patients with macroalbuminuria had greater concentrations of inflammatory parameters (hs-CRP) than normo-or microalbuminuric patients with type-1 DM with highly statistically significant differences $(p<0.001)$ and we discovered that although IL-18 levels in macroalbuminuric type-1 diabetic patients were greater than which in normo-or micro-albuminuric patients, still with statistically non significant differences.

For blood pressure measures we found that micro-and macroalbuminuric patients have elevated levels of BP than normoalbuminuric patients giving us a question about the role of hypertension in microvascular complications assisting the chronic inflammation role in developing DN. 


\section{Correlations:}

Using the Spearman's rank correlation coefficient (rho) test for correlations and taking the 30 diabetic patients as one group, there is a strong positive correlation between UAE and levels of hS-CRP a correlation coefficient $(r)$ of 0.765 , $(p<0.001)$ and between serum creatinine levels and levels of UAE $(r=0.84, p<0.001)$ Fig. (1).

In addition, there is a moderate positive correlation between duration of DM and levels of $\mathrm{hS}$ CRP $(r=0.687, p<0.001)$, between UAE and levels of IL-18. ( $r=0.453, p=0.012)$, between duration of DM and levels of IL-18 ( $r=0.44, p=0.015)$, between duration of DM and levels of UAE ( $r=0.686$, $p<0.001)$, between UAE and levels of SBP ( $r=$
$0.634, p<0.001)$ and between UAE and levels of $\operatorname{DBP}(r=0.597, p<0.001)$ Fig. (2).

Also, it was found a weak positive correlation between levels of hs-CRP and levels of IL-18 ( $r=$ $0.339, p=0.067)$. Meanwhile, it was found a negative moderate correlation between $\mathrm{HbA}_{1 \mathrm{c}}$ levels and levels of UAE ( $r=0.046, p=0.809$ ) Fig. (3).

Systolic and diastolic blood pressure showed a significant positive correlation with UAE ( $r=$ $0.634, p<0.001)$ and $(r=0.597, p<0.001)$ respectively as studies proved that hypertension was present in approximately one third of patients with type 1 diabetes, while hypotension was detected only in severe autonomic neuropathy causing postural hypotension in type 1 diabetic patients.

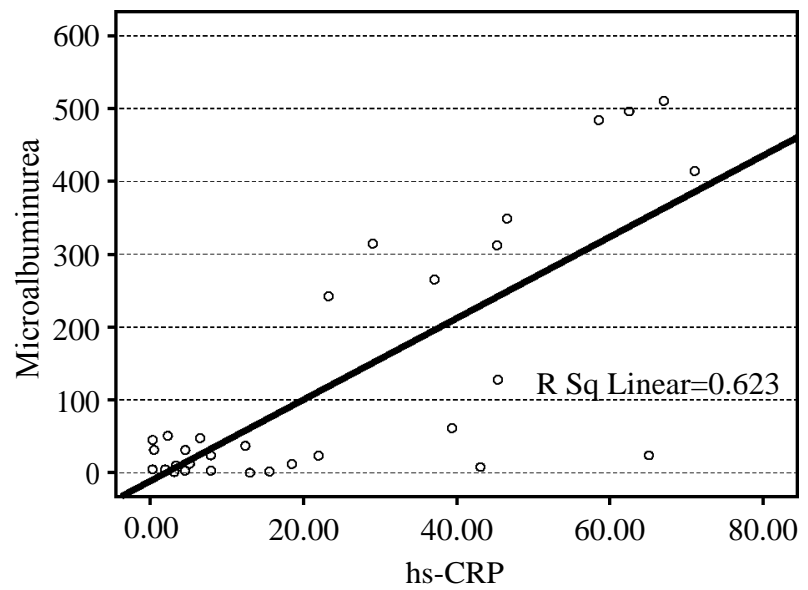

\begin{tabular}{|l|c|l|}
\hline & Microalbuminurea & Hs-CRP \\
\hline $\begin{array}{l}\text { Microalbuminurea: } \\
\text { - Pearson Correlation } \\
\quad \text { coefficient }(r)\end{array}$ & 1 & \\
$\cdot$ Sig. (2-tailes) & & 0.765 \\
$\cdot \mathrm{N}$ & 30 & $<0.001$ \\
$H s$ - CRP: & & 30 \\
$\cdot \boldsymbol{r}$ & 0.765 & \\
$\cdot \mathrm{Sig}$. (2-tailed) & $<0.001$ & 1 \\
$\cdot \mathrm{N}$ & 30 & 30 \\
\hline
\end{tabular}

Fig. (1): Correlation between hs-CRP and UAE: This figure shows a significant positive correlation between UAE and hs-CRP.

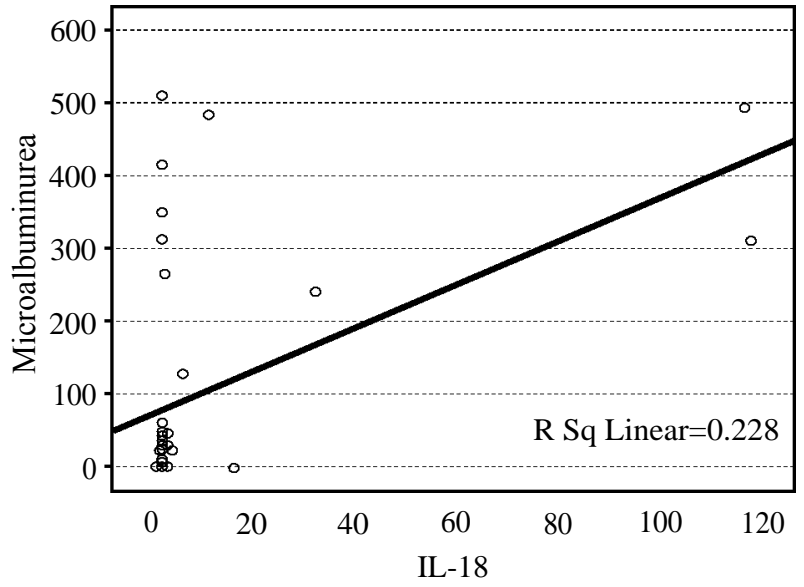

\begin{tabular}{|l|l|c|}
\hline & IL-18 & Microalbuminurea \\
\hline IL-1 8: & & \\
$\bullet r$ & 1 & 0.453 \\
$\bullet$ Sig. (2-tailes) & 30 & 0.012 \\
$\bullet \mathrm{N}$ & & 30 \\
Microalbuminurea: & & \\
$\bullet \boldsymbol{r}$ & 0.453 & 1 \\
$\bullet$ Sig. (2-tailed) & 0.012 & 30 \\
$\bullet \mathrm{N}$ & 30 & 30 \\
\hline
\end{tabular}

Fig. (2): Correlation between IL-18 and urinary albumin excretion: This figure shows a moderate positive correlation of UAE with IL-18. 


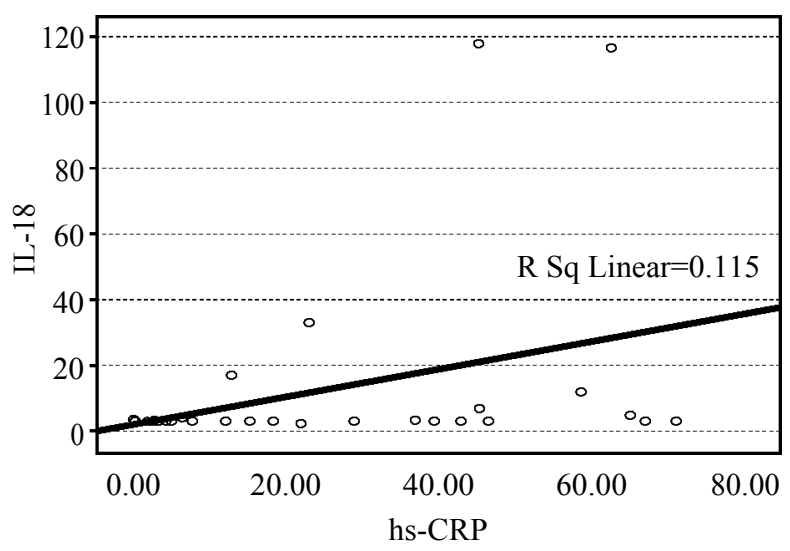

\begin{tabular}{|l|l|l|}
\hline & IL-18 & Hs-CRP \\
\hline$I L-18:$ & & \\
$\bullet r$ & 1 & 0.339 \\
$\cdot$ Sig. (2-tailes) & 30 & 0.067 \\
$\cdot \mathrm{N}$ & & 30 \\
$H s-C R P:$ & 0.339 & 1 \\
$\bullet r$ & 0.067 & \\
$\cdot$ Sig. (2-tailed) & 30 & 30 \\
$\cdot \mathrm{N}$ & & \\
\hline
\end{tabular}

Fig. (3): Correlation between IL-18 and hs-CRP: This figure shows a weak positive correlation of hs-CRP with IL-18.

\section{Discussion}

The present study was designed to determine the role of Interleukin-18 and highly sensitive Creactive protein in diabetic nephropathy in type1 diabetic patients. The current study results indicate that diabetic patients showed significantly higher levels of hs-CRP and IL-18 than did the controls. Mahmoud et al., [11] reported that after doing a cross-sectional study on 65 diabetic patients [30 with type 1 Insulin Dependent Diabetes Mellitus (IDDM) and 35 with type 2 Non-Insulin Dependent Diabetes Mellitus (NIDDM)] the levels of IL-18 were significantly higher in both IDDM and NIDDM individuals as compared to the control group. Similarly, IL-18 levels in patients with diabetic nephropathy increased gradually according to the clinical stage of the disease, being highest in macroalbuminuric stage suggesting that high serum levels of IL-18 might play a role in the pathogenesis of DM and in the development of nephropathy in diabetic patients whether of type 1 or type 2 .

Moreover, Coulon et al., [12] reported that after doing a cross-sectional study on 126 patients of type-1 diabetes with group having diabetic nephropathy that hs-CRP concentrations were significantly higher in these type- 1 diabetic patients than in the controls and he discovered significant correlations between hs-CRP and age or duration of diabetes and he discovered that levels of hs-CRP were 3-fold greater in diabetic patients without complications than in controls and 5-fold greater in diabetic patients with subclinical complications as nephropathy suggesting that hs-CRP therefore appears to be an interesting indicator of the risk for developing complications.

Recently, Yaribeygi et al., [13] stated that IL18 as an inflammatory marker was expressed in renal tissues and upregulated by several stimuli including hyperglycemia, they also mentioned that urinary IL18 was positively correlated with the progression of diabetic nephropathy and urinary albumin excretion rate.

However, Zachwieja et al., [14] found normal IL-18 concentrations in type- 1 diabetic patients compared to control group in a study was done on 22 type- 1 diabetic children and 22 controls. This could be due to the difference in the patients ages between their study and ours and or due to the differences in the methods of measurements.

Also, Picardi et al., [15] reported that no differences in the concentrations of hs-CRP between recent onset type-1 DM patients and controls, but hs-CRP levels were significantly increased in these patients after 12 months of intensive insulin therapy showing that, despite good metabolic control, 1 year of overt T1DM is sufficient to increase hsCRP levels. This could be due to the difference in the duration of diabetes between their study and ours.

In our study we noted that low-grade inflammation as determined by serum hs-CRP was already present in the early stage of microalbuminuria, when patients with type-1 DM developed albuminuria, we observed that those with macroalbuminuria had greater concentrations of inflammatory parameters; hs-CRP, than normo-albuminuric patients with type $1 \mathrm{DM}$. The mean levels of hs-CRP have higher statistically significant differences in macroalbuminuric and microalbuminuric patients compared to normoalbuminuric patients.

Overgaard et al., [16] reported that low-grade inflammation was already present in the early stage of microalbuminuria and low-grade inflammatory markers could serve in predicting initiation, and the progression of diabetic nephropathy as it predicted the development of micro- and macroalbu- 
minuria supporting the theory that inflammation is involved in the progression of diabetic nephropathy. His study was on 60 type-1 DM patients where 20 developed microalbuminuria followed by macroalbuminuria and 40 stayed normoalbuminuric during approximately 30 years of followup time was used to evaluate baseline levels of hsCRP.

Also, Marcovecchio et al., [17] who proved that hs-CRP levels were significantly higher in type1 diabetic patients with micro-albuminurea when compared with normoalbuminuric type-1 diabetic patients.

Recently, Liu et al., [18] confirmed that the levels of hs-CRP are higher in macro-albumiuria than micro-albumiuria and normo-albuminuia groups, and it could be used as an indicator of progression of diabetic nephropathy in diabetes mellitus patients. Moreover, Varma et al., [19] reported that hs-CRP levels were significantly correlated to the fasting blood glucose, two hours post prandial, $\mathrm{HbA}_{1 \mathrm{C}}$ and urinary microalbuminuria. And they stated that it may increase the microangiopathic complications of diabetes mellitus.

Conversely, Hansen et al., [20] reported higher CRP concentrations in patients with normoalbuminuria or microalbuminurea than macroalbuminuria. hs-CRP were measured in 1,564 type 1 diabetes patients showed that hs-CRP levels were significantly associated with progression from normal albumin excretion rate to microalbuminuria, but the association was only borderline significant after adjustment for macroalbuminuria. This could be due to the difference in the patients ages and race between their study and ours.

Results of the present study showed that the mean levels of IL-18 in the three diabetic subgroups were $(4.5 \pm 4.396) \mathrm{ng} / \mathrm{l},(3.5 \pm 1.29) \mathrm{ng} / \mathrm{l}$, and (30.05 $\pm 47.009) \mathrm{ng} / \mathrm{l}$ in patients with normo-albuminuria, microalbuminuria and macro-albuminuria respectively with borderline significant difference between the three groups $(p=0.064)$. Kuryliszyn et al., [21] found that IL-18 levels increase with macroalbuminuria as diabetic patients with severe microvascular changes and nephropathy showed significantly higher IL-18 level.

In addition, Fujita et al., [22] showed that IL18 and hs-CRP were significantly elevated only in the severe nephropathy group but did not significantly elevate in other diabetic complications suggesting effect of IL-18 on glomerulus in addition to its proinflammatory effect and proposed that
IL-18 has a specific role that contributes more closely to the progression of diabetic nephropathy than other diabetic complications.

However, Altinova et al., [23] reported that IL18 does not differ in diabetic nephropathy group comparison to patients without microvascular complications but he noted that IL-18 levels were elevated in all type-1 diabetic patients compared to control group. Furthermore, Moriwaki et al., [24] showed higher IL-18 concentrations in patients with micro-albuminuria than macro-albuminuria. This could be due to the difference in the experimental duration of diabetes between their study and ours and or due to the differences in the methods of measurements.

By using the Spearman rho test for correlations between the diabetic groups, we found that there was a positive significant correlation between hsCRP, IL-18 and duration of DM. This indicates that the extent of inflammatory cell accumulation in the kidney is closely associated with DN. Indeed, inhibition of inflammatory cell recruitment into the kidney has been shown to be protective in experimental diabetic nephropathy [6]. Coulon et al., [12] conducted their study on 126 type-1 diabetic patients to investigate whether high sensitivity hsCRP levels are elevated in young T1D patients and to determine the relationships with age, degree of metabolic control determined by glycated hemoglobin $\left(\mathrm{HbA}_{1_{\mathrm{c}}}\right)$, and subclinical complications found that significant correlations were observed between hs-CRP and age or duration of diabetes with no correlation was observed between hs-CRP levels and glycaemia; $\mathrm{HbA}_{1_{\mathrm{c}}}$, suggested that chronic exposure to glucose could stimulate the production of hs-CRP.

Also, Marcovecchio et al., [17] found that the duration of diabetes was independently related to hs-CRP suggested that chronic exposure to glucose could stimulate the production of hs-CRP as there was a significant increase in hs-CRP levels after the onset of microalbuminurea, likely reflecting a general state of inflammation. In addition, Altinova et al., [23] found that the duration of diabetes was independently related to IL-18 suggested that chronic exposure to glucose could stimulate the production of IL-18.

On the other hand, Kilpatrick et al., [25] showed that the duration of diabetes was unrelated to level of hs-CRP in study done on 167 type 1 patients with different duration of disease. This could be due to the difference in the experimental duration of diabetes between their study and ours. 
Our results showed a weak correlation found between hs-CRP and IL-18. In our study IL-18 might not be a predictor of progression of diabetic nephropathy with hs-CRP. Our results disagree with Nakamura et al., [26] whose study was conducted on 82 diabetic patients were randomly assigned, they found that CRP elevation was positively correlated to IL-18 elevation suggesting that IL-18 might be a predictor of progression of diabetic nephropathy.

Our study data showed that the Association between UAE and the levels of inflammatory markers of hs-CRP and IL-18 was found with a significant positive correlation. This indicates that the extent of inflammatory cell accumulation in the kidney is closely associated with DN. Indeed, inhibition of inflammatory cell recruitment into the kidney has been shown to be protective in experimental diabetic nephropathy. Together, these results suggest that inflammation may be a pathogenic factor for the development and progression of DN.

Marcovecchio et al., [17] reported that after doing a study on 98 patients with T1DM and further divided into 2 groups; normoalbuminurics and patients with development of microalbuminuria of 49 patients each. Serum concentrations of hs-CR had been analyzed and studied their correlation with proteinuria showing a progressive rise in hsCRP levels significantly in the years after the onset of the development of microalbuminuria when compared with levels before development of microalbuminuria onset. Also, Mojtahedi et al., [27] who found high levels of inflammatory markers; hsCRP in 87 diabetic patients when were correlated to the albumin excretion in urine, microalbuminuria is accompanied by elevated HS-CRP, suggesting activation of inflammatory pathways in progression of renal and cardiovascular atherosclerotic disease.

Data of the present study showed nonsignificant relationship between UAE and HbA1c levels. This is in accordance with Cizmecio olu et al., [28] who proved that association between urine albumin excretion and $\mathrm{HbA}_{1 \mathrm{c}}$ are not independent. On the other hand, Oslen et al., [29] have reported that urine albumin excretion had a significant association with $\mathrm{HbA}_{1 \mathrm{c}}$

Our results showed a weak correlation between serum creatinine and albuminuria. Krolewski et al., [30] proved that the association between urine albumin excretion and serum creatinine are independent. The present study showed a positive significant correlation found between hypertension and albuminuria. Lithovius et al., [31] found that the prevalence of hypertension was $1.2 \%$ in the normoalbuminuric, $4.7 \%$ in the microalbuminuric, $28.1 \%$ in the macroalbuminuric, $36.6 \%$ in the dialysis, and $26.3 \%$ in the kidney transplant groups in his study.

In addition, Chillaron et al., [32] found that hypertension was present in approximately one third of patients especially in men, those with microangiopathy, overweight or obesity, older age and longer diabetes duration and they noticed that hypertension prevalence increased in parallel to the degree of renal impairment.

In conclusion, the study confirmed that the hsCRP and IL-18 are sensitive markers of diabetic nephropathy in type- 1 diabetic patients. Also, the study confirmed the increased concentrations of hs-CRP and IL-18 in type-1 diabetic patients and the significant association between them and UAE represent the start of inflammatory process of nephropathy and the levels of inflammatory cytokines increase with the development of kidney damage. So hs-CRP and IL-18 can be used as markers for predicting diabetic nephropathy in type-1 diabetic patients.

\section{References}

1- FORBES J.M. and COOPER M.E.: Mechanisms of diabetic complications. Physiol. Rev. Jan., 93 (1): 137-88, 2013.

2- CANNON A., HANDELSMAN Y., HEILE M. and SHANNON M.: Burden of Illness in Type 2 Diabetes Mellitus. J. Manag. Care Spec. Pharm., Sep., 24 (9-a Suppl): S5S13, 2018.

3- CLERY P., STAHL D., ISMAIL K. , TREASURE J. and KAN C.1.: Systematic review and meta-analysis of the efficacy of interventions for people with Type 1 diabetes mellitus and disordered eating. Diabet. Med., Dec., 34 (12): 1667-75, 2017.

4- WAGNEW F., ESHETIE S., KIBRET G.D., ZEGEYE A., DESSIE G., MULUGETA H. and ALEMU A.: Diabetic nephropathy and hypertension in diabetes patients of subSaharan countries: A systematic review and meta-analysis. BMC Res. Notes. Aug. 6, 11 (1): 565, 2018.

5- IYENGAR R., FRANZESE J. and GIANCHANDANI R.: Inpatient Glycemic Management in the Setting of Renal Insufficiency/Failure/Dialysis. Curr. Diab. Rep., Aug., 15; 18 (10): 75, 2018.

6- DONATE-CORREA J., MARTÍN-NÚÑEZ E., MUROSDe-FUENTES M., MORA-FERNÁNDEZ C. and NAVARRO-GONZÁLEZ J.: Inflammatory Cytokines in Diabetic Nephropathy. Journal of Diabetes Research, 2015: 948417, 2015.

7- LIN Y.C., CHANG Y.H., YANG S.Y., WU K.D. and CHU T.S.: Update of pathophysiology and management of diabetic kidney disease. J. Formos. Med. Assoc., Aug., 117 (8): 662-75, 2018 
8- ARNOLD L.W., HOY W.E. and WANG Z.: The association between C-reactive protein levels and the risk for chronic kidney disease hospitalizations in adults of a remote Indigenous Australian community-A prospective cohort study. Nephrology (Carlton), Sep., 22 (9): 699705, 2017.

9- ELSHERBINY N.M. and AL-GAYYAR M.M.: The role of IL-18 in type 1 diabetic nephropathy: The problem and future treatment. Cytokine, May, 81: 15-22, 2016.

10- CHO N.H., SHAW J.E., KARURANGA S., HUANG Y., Da ROCHA FERNANDES J.D., OHLROGGE A.W. and MALANDA B.7.: IDF Diabetes Atlas: Global estimates of diabetes prevalence for 2017 and projections for 2045 . Diabetes Res. Clin. Pract., Apr., 138: 271-81, 2018.

11-MAHMOUD R., EL-EZZ S. and HEGAZY A.: Increased serum levels of interleukin-18 in patients with diabetic nephropathy. Ital. J. Biochem., Jul., 53 (2): 73-81, 2004.

12- COULON J., WILLEMS D. and DORCHY H.: Increase in C-reactive protein plasma levels during diabetes in infants and young adults. Presse. Med., 34: 89-93, 2005.

13-YARIBEYGI H., ATKIN S.L. and SAHEBKAR A.: Interleukin 18 and diabetic nephropathy. J. Cell Physiol., Nov. 11 doi, 2018.

14-ZACHWIEJA J., SOLTYSIAK J., FICHNA P., LIPKOWSKA K., STANKIEWICZ W., SKOWRONSKA B., KROLL P. and LEWANDOWSKA-STACHOWIAK M.: Normal-range albuminuria does not exclude nephropathy in diabetic children. Pediatr. Nephrol., Aug., 25 (8): $1445-$ $51,2010$.

15-PICARDI A., VALORANI M., VESPASIANI GENTILUCCI U., MANFRINI S., CIOFINI O., CAPPA M., GUGLIELMI C. and POZZILLI P.: Raised C-reactive protein levels in patients with recent onset type 1 diabetes. Diabetes Metab. Res. Rev., Mar., 23 (3): 211-4, 2007.

16- OVERGAARD A., McGUIRE J., HOVIND P., PARVING H., ROSSING P .and POCIOT F.: Serum amyloid A and C-reactive protein levels may predict microalbuminuria and macroalbuminuria in newly diagnosed type 1 diabetic patients. J. Diabetes Complications. Jan.-Feb., 27 (1): 5963, 2013.

17- MARCOVECCHIO M., GIANNINI C., WIDMER B., DALTON R., MARTINOTTI S., CHIARELLI F. and DUNGER D.B.: C-reactive protein in relation to the development of microalbuminuria in type 1 diabetes: The Oxford Regional Prospective Study. Diabetes Care, May, 31 (5): 974-6, 2008.

18- LIU Q., JANG C.Y., CHEN B.X., ZHAO W. and MENG D.: The association between high sensitive CRP and diabetic nephropathy. Eur. Rev. Med. Pharmacol. Sci. Dec., 19 (23): 4558-68, 2015.

19- VARMA V., VARMA M., VARMA A., KUMAR R., BHARASAY A. and VYAS S.: Serum total sialic acid and highly sensitive $C$ reactive protein: Prognostic markers of the diabetic nephropathy J. Lab. Physians. Jan.-Jun., 8 (1): 25-9, 2016

20- HANSEN T., FORSBLOM C., SARAHEIMO M., et al.: Association between mannose-binding lectin, highsensitivity C-reactive protein and the progression of diabetic nephropathy in type 1 diabetes. Diabetologia, Jul., 53 (7): 1517-24, 2010.
21- KURYLISZYN-MOSKAL A.1., DUBICKI A., ZARZYCKI W., ZONNENBERG A. and GÓRSKA M.: Microvascular abnormalities in capillaroscopy correlate with higher serum IL-18 and sE-selectin levels in patients with type 1 diabetes complicated by microangiopathy. Folia Histochem. Cytobiol., 49 (1): 104-10, 2011.

22- FUJITA T., OGIHARA N., KAMURA Y., SATOMURA A., FUKE Y., SHIMIZU C., WADA Y. and MATSUMOTO K.: Interleukin-18 contributes more closely to the progression of diabetic nephropathy than other diabetic complications. Acta Diabetol., Apr., 49 (2): 111-7, 2012.

23- ALTINOVA A., YETKIN I., AKBAY E., BUKAN N. and ARSLAN M.: Serum IL-18 levels in patients with type 1 diabetes: Relations to metabolic control and microvascular complications. Cytokine, May, 42 (2): 217-21, 2008.

24- MORIWAKI Y., YAMAMOTO T., SHIBUTANI Y., AOKI E., TSUTSUMI Z., TAKAHASHI S., OKAMURA H., KOGA M., FUKUCHI M. and HADA T.: Elevated levels of interleukin-18 and tumor necrosis factor-alpha in serum of patients with type 2 diabetes mellitus: Relationship with diabetic nephropathy. Metabolism, May, 52 (5): 6058, 2003.

25- KILPATRICK E., KEEVIL B., JAGGER C., SPOONER R. and SMALL M.: Determinants of raised C-reactive protein concentration in type 1 diabetes. Q.J.M. Apr., 93 (4): 231-6, 2000.

26- NAKAMURA A., SHIKATA K., HIRAMATSU M., NAKATOU T., KITAMURA T., WADA J., ITOSHIMA T. and MAKINO H.: Serum interleukin-18 levels are associated with nephropathy and atherosclerosis in Japanese patients with type 2 diabetes. Diabetes Care, Dec., 28 (12): 2890-5, 2005.

27- MOJTAHEDI Z., NAEIMI S., FARJADIAN S., OMRANI G.R. and GHADERI A.: Association of IL-18 promoter polymorphisms with predisposition to Type 1 diabetes. Diabet Med. Mar., 23 (3): 23 5-9, 2006.

28- CIZMECIOGLU F., NOYES K., BATH L. and KELNAR C.: Audit of microalbumin excretion in children with type I diabetes. J. Clin. Res. Pediatr. Endocrinol., 1: 136-43, 2009.

29- OLSEN B., SJOLIE A. and HOUGAARD P.: The significance of the prepubertal diabetes duration for development of retinopathy and nephropathy in patients with type 1 diabetes. The Danish Study Group of Diabetes in Childhood. J. Diabetes Complications, 18 (3): 160-4, 2004.

30- KROLEWSKI A.S., GOHDA T. and NIEWCZAS M.A. Progressive renal decline as the major feature of diabetic nephropathy in type 1 diabetes. Clin. Exp. Nephrol., Aug., 18 (4): 571-83, 2014.

31- LITHOVIUS R., HARJUTSALO V., FORSBLOM C., SARAHEIMO M. and GROOP P.H.: Antihypertensive treatment and resistant hypertension in patients with type 1 diabetes by stages of diabetic nephropathy. Diabetes Care, Mar., 37 (3): 709-17, 2014.

32- CHILLARÓN J., SALES M., FLORES-Le-ROUX J., MURILLO J., BENAIGES D., CASTELLS I., GODAY A., CANO J.F. and PEDRO-BOTET J.: Insulin resistance and hypertension in patients with type 1 diabetes. J. Diabetes Complications. Jul.-Aug., 25 (4): 232-6, 2011. 


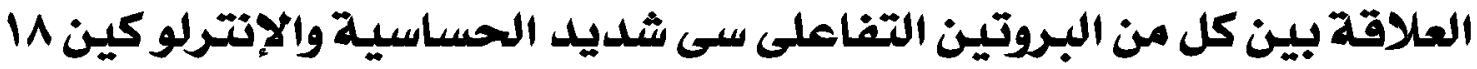

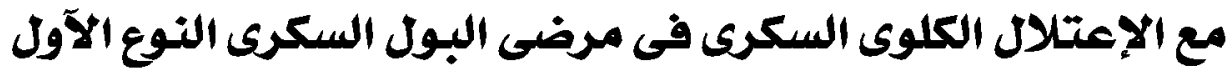

تهذف هذه الدراسة إلى تحديد العلاقة بين كل من البروتين التفاعلى سى شديد الحساسية والإنترلوكين ^\ مع الإعتلال الكوى السكرى

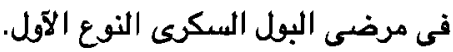

لقد شملت الدراسة ــ مريضا يعانون من مرض البول السكرى النوع الآول وتم تقسيمهم إلى ثلاث مجموعات فرعية وفقا لإفراز الزلال بالبول:

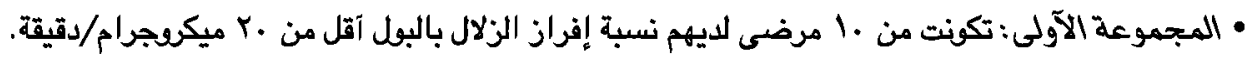

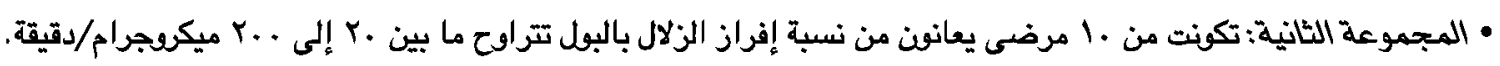
• المجموعة الثالثة: تكونت من • ا مرضى يعانون من نسبة إفراز الزلال بالبول آكثر من . .بميكروجرام/دقيقة.

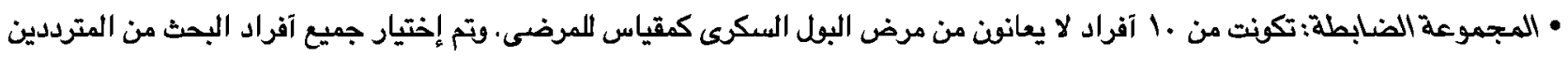

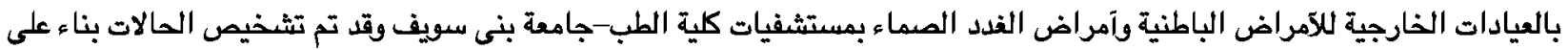

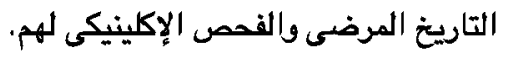

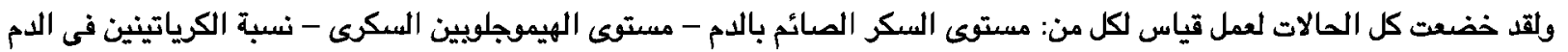
- معدل الزلال فى البول- نسبة البروتين التفاعلى سى شديد الصسا سية بإستخدام تقنية التربيديمترى - نسبة الإنترلوكين ل ل بإستخدام الإليزا.

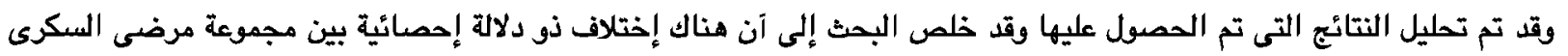

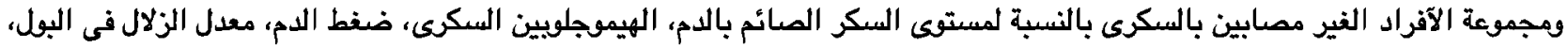

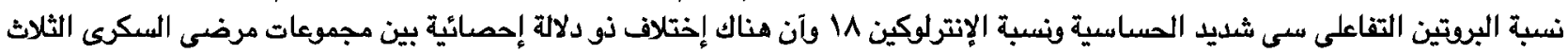

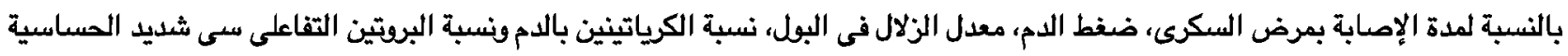

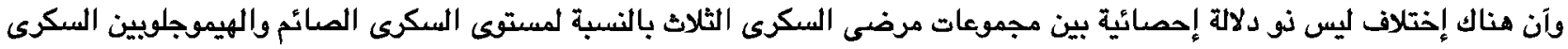

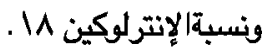

وقد آظهرت النتائج البحث آيضا آن هناك علاقة طردية ذات دلالة إحصائية بين نسبة البروتين التفاعلى سى شديد الحساسية الحية ومعدل الزلالال

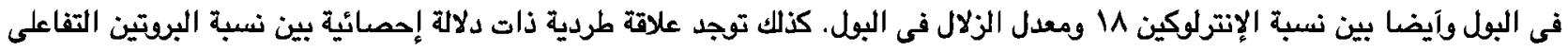

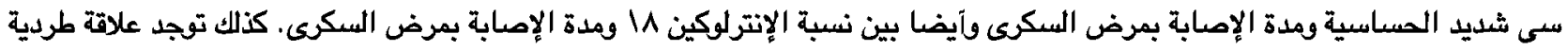

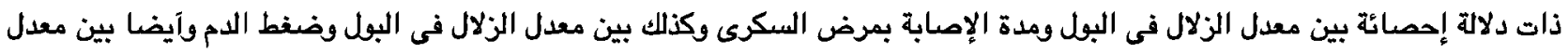
الزلال فى البول ونسبة الكرياتينين بالدم.

$$
\text { وتوصى الدراسة بالآثى: }
$$

ا- يجب متابعة وضبط نسبة السكر بالدم وكذالك التحكم فى ضغط الدم لآنهما من آكبر العوامل لحدوث وتطود الإعتلال الكلوى السكرى فى مرضى البول السكرى النوع الآول.

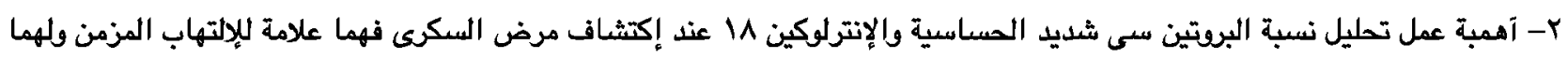

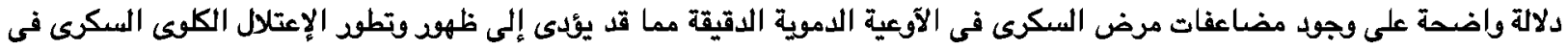

$$
\text { مرضى البول السكرى النوع الآول. }
$$

r- يستحسن عمل تحليل الإنترلوكين \\ للآقارب من الدرجة الأولى لمرضى البول السكرى النوع الآول إيجابى التحليل لآنهم آكثر عرضة للإصابة بالمرض دون غيرهم.

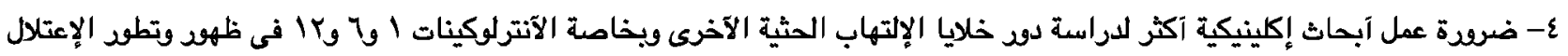
الكلوى السكرى لمرضى البول السكرى النوع الآول. 